\title{
Bildungsroman Bağlamında Süheyl ü Nevbahâr Mesnevisi’ni Okumak ${ }^{1}$
}

\author{
Özkan CİĞA \\ Dr. Öğr. Üyesi, Adıyaman Üniversitesi, \\ Fen Edebiyat Fakültesi, Türk Dili ve Edebiyatı Bölümü \\ ozkanciga@hotmail.com \\ Orcid ID: https://orcid.org/0000-0002-7081-4507
}

\begin{abstract}
Öz
Süheyl ü Nevbahâr mesnevisi, XIV. yüzyılda Hoca Mesûd ve yeğeni İzzeddin Ahmed tarafından Farsçadan Türkçeye çevrilmiştir. Eser, Türk edebiyatında beşeri aşkı konu edinen ilk mesnevi olarak tanınmaktadır. Geleneksel anlatılar içerisinde gerek dil özellikleri gerek kurgusu bakımından önemli bir yer edinen Süheyl ü Nevbahâr mesnevisini bildugsroman çerçevesinde ele almak mümkündür. Anlatının kahramanlarından Süheyl'in eğitimi, karakter olarak olgunlaşması, aldığı eğitim yoluyla karşılaştığı engelleri aşması ve aydınlanması bildungsroman ile uyumludur. Bildungsroman/eğitim romanı başkahramanın (protagonist) olaylar geliştikçe değiştiği, olgunlaştığ Kahramanın çocukluğundan itibaren yaşadığı tinsel değişimi ve tekâmülü konu edinen bildungsromanda, kahraman olgunlaştıkça kim olduğu üzerinde düşünür ve bireysel varlığını kendi eylemleriyle meydana getirir. Ayrıca bildungsromanda olaylar mutlu bir sonuca bağlanır, kahraman ilk gençliğindeki hayallerini geride bırakıp hatalarının üstesinden gelerek kemâle erişir. Süheyl ü Nevbahâr mesnevisinde başkahraman olarak öne çıkan Süheyl’in aldığı eğitim sonucu gelişmesi bir çok açıdan bildungsromanı hatırlatır. Bu çalışmanın amacı Süheyl ü Nevbahâr mesnevisini bildungsroman çerçevesinde ele alarak incelemektir.
\end{abstract}

Anahtar Kelimeler: Bildungsroman, Süheyl ü Nevbahâr, Mesnevi, Olgunlaşma.

\footnotetext{
${ }^{1}$ Makale Geliş/Kabul Tarihi: 31.05.2021 / 02.08.2021

Künye Bilgisi: Ciğa, Ö. (2021). Bildungsroman Bağlamında Süheyl ü Nevbahâr Mesnevisi’ni Okumak. Kahramanmaraş Sütçü İmam Üniversitesi Sosyal Bilimler Dergisi, 18(2), 839-856. DOI: 10.33437/ksusbd.946062
} 


\title{
Reading The Süheyl ü Nevbahâr Masnavi in The Context Of Bildungsroman
}

\begin{abstract}
Süheyl ü Nevbahâr masnavi translated to Turkish from Persian by Hoca Mesud and his nephew İzzeddin Ahmed in XIVth century. This work is recognized as the first masnavi that it is about human love in Turkish literature. Süheyl ü Nevbahâr masnavi that it is taking attention in terms of language features and fiction can discuss in regards to bildungsroman. Süheyl's education, maturation as a character, enlightenment and overcoming obstacles are compatible with bildungsroman. Bildungsroman/education novel is defined as protagonist's maturation and changing as events progressed. In bildungsroman, which mentions of the spiritual change and maturation that the hero has experienced since childhood, protagonist thinks about who he/she is and creats his/her individual existence by his/her activities. Besides, events finish by happy ending and protagonist maturates by overtaking dreams of his/her youth overcoming his/her faults in bildungsroman. In Süheyl ü Nevbahâr masnavi, Süheyl who becomes prominent as a protagonist maturates by education just like bildungsroman. The aim of this paper is to investigation Süheyl ü Nevbahâr masnavi in the context of bildungsroman.
\end{abstract}

Keywords: Bildungsroman, Süheyl ü Nevbahâr, Masnavi, Maturing.

\section{Giriş}

Kimi kurmaca metinlerde kahramanın aldığı eğitim sayesinde olgunlaşma süreci olayların merkezine alınır. XVIII. yüzyılın sonlarına doğru bu türden kurmaca metinler için bildungsroman ifadesi kullanılmaya başlanır. Bildungsroman/eğitim romanı (Alm. Erziehungsroman veya Bildungs), başkahramanın (protagonist) olaylar geliştikçe değiştiği, olgunlaştığ 1 roman türüne denir (Bingöl, 2019: 261). Gürsel Aytaç ise eğitim romanı için şunları söyler: "Bildungsroman, bir insanın akıl ve duygu gibi manevi yeteneklerinin işlenişi, onun yaşadığı çağ ve toplumun istediği biçime girmesini; bu oluşuma katkısı olan maddi ve manevi etmenleri, geçirilen aşamaları, sonunda ulaştı̆̆ 1 kişiliği konu alır" (Aytaç, 1990: 276).

$\mathrm{Bu}$ bağlamda, kaynaklarda bildungsroman kahramanın çocukluğundan itibaren yaşadığı tinsel değişimi ve olgunlaşmayı konu edinen roman şeklinde tanımlanır. Bu tür romanlarda kahraman olgunlaştıkça kim olduğu üzerinde 
düşünür ve bireysel varlığını kendi eylemleri ile meydana getirir. ${ }^{2}$ M. H. Abrams, A Glossary of Literary Terms'te Almanca bildungsroman ve erziehungsroman kelimelerinin İngilizcedeki karşılığı olarak formasyon romanı (novel of formation) ve eğitim romanı (novel of education) ifadelerini verir. Açılamaya göre Abrams, bu roman türlerinin çocukluktan yetişkinliğe kahramanın ruhsal krizler ve çeşitli deneyimler yoluyla zihinsel ve karakter açısından gelişimini anlattığını söyler (Abrams, 1999: 193).

Bu minvalde, "Bildungsroman yani eğitim romanı ile eğitsel roman ve gelişim romanı sık sık birbirine karıştırılmaktadır. Eğitsel romanlar hedef kitleye ahlaki, kültürel, dini veya millî değerleri benimsetmek amacıyla yazılan romanlardır; gelişim romanı ise bir kahramanın davranışlarında ve düşüncelerinde bazı gelişimlerin yaşanması anlamında kullanılır” (Bingöl, 2019: 260). Gelişimin aynı zamanda eğitimin bir ürünü olması, eğitim romanının aynı zamanda bir gelişim romanı olarak algılanmasında etkili olmuştur. İki kavram arasında bazı ayırımlara gidilebilir. Bildungsroman ile gelişim romanı kahramanın gelişim evreleri açısından birbirinden ayrılır. Bildungsromanda kahramanın çocukluk yıllarından başlayarak yetişkinlik çağına kadar öğrenmesine bağlı olarak yaşadığı değişim anlatılırken gelişim romanında kahramanın yaşamındaki bir kesitte gerçekleşen dönüşümler ve değişimler anlatılır. Eğitim romanının aksine gelişim romanında kahramanın gelişimi sosyal ilişkiler çerçevesinde ele alınır. Eğitsel roman ise genellikle bir eğitim kurumunda kahramanın ahlaki gelişimini didaktik tarzda işleyen romanlar olarak tanımlanır. Bu ayırımlara rağmen eğitim romanı ile gelişim romanı arasında bir farkın olmadığını düşünen bazı eleştirmenler her iki kavramı aynı anlama gelecek şekilde kullanırlar.

Bildungsroman modern insanın bireyselleşme eylemini gerçekleştirirken geçirdiği serüvenin romanı olarak değerlendirilir. Son zamanlarda yapılan akademik çalışmalarda bildungsromanının kapsamı genişletilmiş birçok gelişim romanı da bu başlık altında değerlendirilmiştir. Yine bildungsromanın bir türü olan artist-romanda (Künstlerroman), yazarın veya diğer bir sanatçının gelişimi, eğitimi, olgunlaşma süreci anlatılır. Bu türün en iyi örneklerinden biri Joyce'un Bir Genç Adam Olarak Sanatçının Portresi adlı romanıdır (Bingöl, 2019: 262). Jale Parla'ya göre bildungsroman büyüme, bilinçlenme romanı anlamına gelir ve

\footnotetext{
2 Bildungsroman kavramı hakkında kafa karışıklığının olmasının temel nedeni Almanca formasyon, eğitim anlamlarına gelen bildungs ifadesinin İngilizceye veya başka dillere çevrilirken yaşanan sıkıntıdır. Türkçe çalışmalarda olduğu gibi İngilizce yapılan çalışmalarda da bildungsromanın gelişim ve eğitim romanından kimi zaman ayrı ele alındığına tanık olunur. Bize göre bildungsromanın içerisinde gelişim ve eğitimin her ikisi de mevcuttur. Gelişim romanı olarak ayrı bir başlık açmak mümkündür; fakat gelişim romanının karşılığı olarak bildungsromanı vermek mümkün değildir. Çünkü kahramanın eğitim sürecinden geçmeden yaşadığı olaylar neticesinde düşünsel gelişmeler yaşadığı romanlar mevcuttur.
} 
anlatının kronolojik yapısına vurgu yapar. Genellikle yetkin birinin çocukluğundan başlayarak olgunlaşmasına kadar uzanan süreci ele alan bildungsroman, roman kahramanının ne tür seçimlerle karşı karşıya kaldığını ve yaptığı seçimler sonucunda yaşamının nasıl belirlendiğini, neredeyse bir ibret öyküsü gibi anlatır (2012: 260). Bildungsromanda olaylar mutlu bir sonuca bağlanır, kahraman ilk gençliğindeki hayallerini geride bırakarak hatalarının üstesinden gelerek olgunlaşır. Michael Minden'e göre bildungsromanda üstedinden gelinmesi gereken kötü bir durum olayların başlangıcı olarak öne çıkar. Roman kahramanının çıktığı yolculuk, gelişimini tamamlamasına ve olgunlaşmasına hizmet eder (1997: 5).

Tüm bu anlatılardan hareketle Bildungsromanın temel özellikleri şöyle siralanabilir:

1. Bildungsroman başkahramanın çocukluk yıllarından başlayarak ahlak, düşünce ve duygu açısından gelişimini konu alır.

2. Başkahraman bir meslekte veya bir sanat dalında uzmanlaşırken de tinsel dönüşüm içine girer.

3. Okuyucu, başkahramanın karşılaştığı engelleri aşarken onun karakter olarak gelişimini gözlemler.

4. Bildungsroman bireysel yaşamdaki düzenli gelişimdir. Anlatının her bir evresi ayrı bir değerdir ve bir üst evrenin temelini oluşturur (Dilthley, 1985: 380).

5. Kahramanın eğitiminde genellikle onun yanında olan, ona yol gösteren, karşılaştı̆g sorunları aşmasında onu bilgilendiren birileri bulunabilir.

6. Kahramanın gelişimi ve engelleri aşması, başlı başına anlatının mesajını içerir.

7. Bildungsromanda hikâyenin başlarında kahraman kendisiyle ilgili bir eksiklik hisseder veya bir şeylerin kaybını yaşar, daha sonra yolculuğa çıkar. Kahramanın ruhsal ve düşünsel gelişimi büyük bir oranda bu yolcukla beraber şekillenir. Kahramanın çıktığı yolculuk aynı zamanda eğitim süreci olarak değerlendirilebilir.

8. Kahraman bazı değer çatışmalarının içine sürüklenebilir fakat olaylar geliştikçe ve öğrendikçe mensubu olduğu grubun değerlerine uyum gösterir ve toplum tarafından kabul görür.

Bildungsroman temelde modern bir terim olmasına karşın işaret ettiği anlamlar ve kapsamı ele alındığında bazı geleneksel metinlerin bu terim 
çerçevesinde değerlendirilebileceği görülmektedir. ${ }^{3}$ Geleneksel anlatılar içesinde gerek dil özellikleri gerek kurgusu bakımından önemli bir yer edinen Süheyl ü Nevbahâr mesnevisini bildugsroman çerçevesinde ele almak mümkündür. Anlatının kahramanlarından Süheyl'in eğitimi, karakter olarak olgunlaşması, aldığı eğitim yoluyla karşılaştığı engelleri aşması ve aydınlanması bildungsroman ile uyumludur. Bundan sonraki kısımda Süheyl ü Nevbahâr mesnevisi hakkında kısaca bilgi verildikten sonra bu mesnevi bildungsroman çerçevesinde incelenecektir.

\section{Genel Olarak Süheyl ü Nevbahâr Mesnevisi}

Süheyl ü Nevbahâr mesnevisi, XIV. yüzyılda Hoca Mesûd ve yeğeni İzzeddin Ahmed tarafindan Farsçadan Türkçeye çevrilmiştir. Eser, Türk edebiyatında beşeri aşkı konu edinen ilk mesnevi olarak tanınmaktadır. Eski Anadolu Türkçesinin karakteristik dil özelliklerini barındırmaktadır. Eser, aruzun fe'ûlün $f e^{\prime}$ ûlün fe'ûlün fe'ûl kalıbıyla yazılmış olup eserde ayrıca farklı vezinlerle de yazılmış gazellere rastlanmaktadır. Mesnevi yazım düzenine göre kaleme alınan bu eserde, Besmele, Hz. Muhammed ve Dört Halife için naat, hikmet ve nasihate dair hususlar ile kitabın yazılış nedenine yer verildikten sonra hikâyenin anlatımına başlanır. Hikâyenin anlatımından sonra kitabın tamamlanmasıyla ilgili bölüme yer verilir. Atasözleri ve deyimler gibi özlü sözlerin yer aldığı bu eserde; dostluk, iyilik, cömertlik, alçakgönüllülük, vefakârlık, yalan söylememek, sabırlı olmak, cesur olmak ve adaletli davranmak gibi daha pek çok konuya değinilir (Dilçin, 1991: 9-68; Ciğa, 2013: 1-5).

Yemen padişâhının oğlu Süheyl ile Çin hükümdarının kızı Nevbahâr arasındaki aşkı anlatan mesnevinin özeti ise şöyledir:

Yemen ülkesinin hükümdarı Bahr'ın çocuğu yoktur. Bahr, bu duruma çok üzülür ve malının büyük bir kısmını halka dağıtır. Halkın duasını alan Bahr'ın bir çocuğu olur ve ona Süheyl ismini verir. Süheyl dadılar tarafindan emzirilir, yedi yaşına gelince ilim ve hüner sahibi biri olur. Süheyl, belli bir birikime ulaşınca babası ona hazinelerini bağışlar ve onu tahta çıkarır.

Süheyl, birgün babasının hazinelerinin yer aldığı odaları gezerken bir odanın anahtarının kendinde olmadığını fark eder. Anahtarı, babasından habersizce alarak odanın içine girer. Odada cennet gibi bir bahçe ve altından yapılmış bir taht vardır. Tahtın önünde ise büyükçe bir havuz bulunur. Süheyl, tahtın üzerine oturduğu sırada tahtın önünde bulunan havuzda Nevbahâr'ın kubbedeki resminin yansımasını görür ve ona âşık olur. Kendinden geçip tahttan yere düşen Süheyl,

3 Klasik Türk edebiyatındaki bazı mesnevilerin kurgu bakımından bildungsromanı hatırlattığı görülür. Bu bağlamda önemli tespitleriyle öne çıkan çalışmalar mevcuttur. (bk. Dursun Ali Tökel 2009; Yavuz Bayram 2007; Rıfat Kütük 2004). 
sürekli ağlar ve günlerce bir şey yemez, içmez. Babası bu duruma çok üzülür ve bu resmin kime ait olduğunu araştırır. Bu resmin Çin hükümdarının kızının resmi olduğu anlaşılınca Süheyl, resmi yapan Nakkaş'la birlikte kızı aramak üzere Çin'e doğru yola çıkar. Nakkaş'ın tavsiyesi üzerine Süheyl, gittiği ülkelerin şâhına ve halkına çeşitli ihsanlarda bulunur ve onları yemeğe davet eder. Süheyl, Çin'e vardığında aynı şekilde Çin hükümdarına ve halkına da ikramlarda bulunur. Böylece ülke, Süheyl'in iyi ahlakı ile cömertliğinden söz eder hâle gelir.

Çin hükümdarı, Süheyl'i yakından tanıma firsatı bulur ve ona kendi şehrinde bir saray yaptırabileceğini söyler. Nakkaş, Nevbahâr'ın sarayına yakın bir yerde güzel bir saray yaptırır. Nevbahâr, sarayın damına çıktıkça Süheyl onu görür ve ona karşı beslediği sevgi daha da şiddetlenir. Nevbahâr da Süheyl'i görünce ona âşı olur. Bir süre sonra daha fazla görüşebilmek için Süheyl ile Nevbahâr yer altında bir tünel kazar ve kendilerine yer altında bir oda yaparlar.

Nevbahâr'la mutlu, mesut günler geçirdikten sonra Süheyl, Nevbahâr'a annesini ve babasını özlediğini bu yüzden Yemen'e dönmek istediği söyler. Süheyl ile Nevbahâr, Çin hükümdarının yanından kaçmak için bir plan uygular, ancak plan istedikleri gibi gerçekleşmez. Süheyl, görüşmek için planlanan yerde uyuyakalınca Nevbahâr, Süheyl sandığı Saluk'un peşinden yol almaya başlar. Böylece Süheyl ile Nevbahâr istemeden birbirlerinden uzaklaşırlar. Birbirlerine kavuşmak için yaptıkları yolculuk sırasında çölde aç ve susuz kalırlar, zindana düşerler ve pek çok sıkıntılarla karşılaşırlar. Süheyl'in rakipleri olan Saluk, Kaytas ve Cühûd ise Nevbahâr'a âşık olup onu elde etmeye çalışırlar. Başlarından geçen uzun bir maceranın ardından Süheyl ile Nevbahâr birbirlerine kavuşur ve Hümam adında bir erkek çocukları olur. Süheyl, bulunduğu ülkenin tahtını oğlu Hümam'a bırakarak Yemen'e gider. Süheyl'in babası hastalanınca babasının vasiyeti üzerine Süheyl, Yemen ülkesinin hükümdarı olur (Ciğa, 2013: 5-9).

\section{Bildungsroman Olarak Süheyl ü Nevbahâr Mesnevisi}

Bildungsroman başkahramanın çocukluk yıllarından başlayarak ahlak, düşünce ve duygu açısından gelişimini konu alır. Söz konusu mesneviye baktığımızda başkahraman olarak Süheyl'in eğitimi de çocukluk yıllarından itibaren başlar. Süheyl, doğduktan sonra babası, onu besleyip belirli bir yaşa getirmeleri için on dadıya emanet eder. Yedi yaşına gelince Süheyl, çeşitli ilimleri öğrenir, hüner sahibi ve ok atmayı iyi bilen biri hâline gelir. Bu durum, bildungsromanın genel özellikleri arasında sıralayabileceğimiz düzenli bir gelişim örneğidir. Mesnevide yer alan ilgili bölüm aşağıdaki şekilde yer alır: ${ }^{4}$

${ }^{4}$ Bu bölüm için Süheyl ü Nevbahâr mesnevisinden aktarılan örnek beyitler ve günümüz
Türkçesiyle nesre çevirileri Süheyl ü Nevbahâr (Metin-Aktarma, Art Zamanlı Anlam
Değişmeleri, Dizin) adlı çalışmadan alıntılanmıştır. Her alıntının sonunda çalışmada 
“Çü toldı tokuz ay [u] geldi haber

Ki Tangrı sana virdi kaygun gider

Bir oğlan ki benzer yüzi bedr aya

İki kaşı dahı kurulmış yaya

Açup yüzüni gördi buldı murâd

Ol aya muvâfik Süheyl urdı ad

Ana süt virüp bisledi on taya

Kalan kullık idenleri kim saya

Zamân ile toldı yidi yaş ana

Bulınmazdı âlemde bendeş ana

Şunun bigi ögrendi ol dânişi

Ki bahs idemezdi anunla kişi

Eline çü yay alup ok atadı

Ger elmâsa urur ise batadı

Hüner cümlesi ana ma’lûm idi

Elinde her iş sanasin mûm idi

Şâh anı görüp güvenürdi canı

Dilerdi ki tahta geçüre anı
Dokuz ay dolunca Allah ona erkek bir çocuk verdi; üzülme diye haber geldi.

Yüzü dolunaya, kaşı da kurulmuş yaya benzeyen bir oğlan çocuğuydu.

Yüzünü açıp muradına erdi; o ay yüze uygun olarak Süheyl adını verdi.

On dadı onu emzirerek besledi; onun için geriye kalan hizmet edicileri kim saysin?

Zamanla yedi yaşına geldiğinde dünyada eşi benzeri bulunmuyordu.

O, bilgiyi öyle öğrendi ki kimse onunla tartışamazdl.

Eline yay alıp ok attı̆̆ında elması bile delerdi.

Bütün sanatları bilirdi; her şey ona kolay gelirdi.

Şâh onu gördü̈̆ünde rahatlardl; onu tahta geçirmeyi isterdi. (404-412)"

Süheyl, belirli bir birikime gelince Bahr, vezirlerine danıştıktan sonra oğlunu tahta çıkarır. Her yeni gelișim bir sonraki üst evrenin temelini olușturma bağlamında Süheyl, belirli bir eğitim düzeyine geldikten sonra babasının gözünde ülkeyi yönetme yetisine erişir:

bulunan beyit numaralarına yer verilmiş̧tir. Konunun kapsamı gereği alıntılanan beyitlerde transkripsiyon işaretleri kullanılmamıştır. 
“Cihânda anun bigi bir şâh yok

Felekde anun bigi bir mâh yok

Hüner-mend ü cömerd ü dânâ durur

Hıred-mend ü hûb u tüvânâ durur

Size oğlumı şâh iderven bugün

Çü ol var durur ben niderven bugün

Pes ağdurdı tahta dutuban elin

Kodı başına tâc u virdi ilin
Yeryüzünde onun gibi bir şâh yok; gökyüzünde onun gibi bir ay yok.

Sanatkâr, cömert ve bilgilidir; akılll, yakışıklı ve güçlüdür. (424-425)”

Bugün oğlumu size hükümdar yapayım çünkü o olduktan sonra bana gerek kalmadl.

Sonra elinden tutarak onu tahta çıkardl; başına taç koydu, ülkesini ona verdi. (435-436)"

Süheyl, tahta geçtikten sonra babasının kendisine verdiği hazineleri görmek ister. Süheyl, hazine odalarını gezerken bir odanın anahtarının kendinde olmadığını farkeder. Babasından izin almadan bu odanın anahtarını gizlice alıp odayı açar ve Nevbahâr'ın resmiyle karşılaşır. Nevbahâr'ın resmine âş̧ı olan Süheyl kendinden geçer ve gece gündüz ağlar. Süheyl için çok üzülen baba, onu bu sevdadan vazgeçirmek için ona duvardaki resme gönül bağlamaması gerektiğini, o resmin bir hayal ürünü olduğunu, çaresi olmayan bu sevdadan vazgeçip zamanını zevk içinde geçirmesi gerektiğini yoksa halk tarafından ayıplanacağını öğütler. Ancak Süheyl, bu öğütleri dinlemez.

Mesnevide geçen bu olaylar, bildungsroman bağlamında düşünüldüğünde hikâyenin başlarında kahramanın kendisiyle ilgili bir eksiklik hissetme veya bir şeylerin kaybını yaşama durumuyla paralellik gösterdiği görülmektedir.

Mesnevinin devamında Süheyl'in babası, vezirinin aracılığıyla resmi yapan Nakkaş'ı bulur. Nakkaş, kubbeye işlediği resmin Çin hükümdarının kızının resmi olduğunu söyleyince Süheyl, kendine gelir. Süheyl, Nakkaş'1n tavsiyesi üzerine Çin'e gitmek için babasından izin alır. Ancak Süheyl, daha önce gurbette bulunmadığı, henüz genç ve tecrübesiz olduğu için ve evlat ayrılı̆̆ına dayanamayacağı için babası Süheyl'e ilk önce izin vermez. Vezir, Süheyl'in babasına Süheyl'in naz ile büyütüldüğünü, gurbete düşüp zahmet çekmesi gerektiğini, gurbette aç kalıp sıkıntı çektikten sonra yorulup bu sevdadan vazgeçeceğini, dostunu ve düşmanını tanıyarak dünyanın işinin nasıl olduğunu anlaması gerektiğini söyledikten sonra giden kişinin yoluna engel olunamayacağını ifade eder. Bahr, oğlunu Çin'e gitmemesi için yine ikna etmeye çalışır. Ancak Süheyl, kendisinde aklın ve şuurun kalmadığını söyleyerek 
babasına itiraz eder. Süheyl'in durumu, eskisinden daha kötü bir hâl alınca vezirin önerisi üzerine Bahr, Çin'e gitmesi için oğluna izin verir.

$\mathrm{Bu}$ durum eserin kahramanını doğrudan bildungsroman çerçevesine taşır. Nitekim bildungsroman kapsamında yazılan eserlerde kahraman, yaşamındaki eksikliğin farkına varıp uzun bir yolculuğa çıkar. Aynı şekilde kahramanın ruhsal ve düşünsel gelişimi büyük bir oranda bu yolcukla beraber şekillendiği görülür. Kahramanın çıktığı yolculuk aslında kahramanın eğitim süreci olarak da değerlendirilebilir.

Süheyl de babasının tüm itirazlarına rağmen Vezir'in de ikna çabalarıyla yolculuğa çıkar. Vezir tarafindan Süheyl'in babasına söylenen sözler, tamamen Süheyl'in ruhsal ve düşünsel gelişimini tamamlaması adına dile getirilen tavsiyelerdir. Ayrıca Vezir, yolculuk sırasında Süheyl'in edineceği tecrübe ile kendi hatasının farkına varıp içine düştüğü sevdadan vazgeçeceği ve tekrar yurduna döneceğini de ifade eder. Mesnevide söz konusu olayların geçtiği bölüm ise şöyledir:

"Vezîr eydür iy pâdişâh-ı cihân

Tapunda benüm bir sözüm var hemân

Bilün kim bu şâh-zâdemüz kiçiden

Eyü hulk gördi ulu kiçiden

Gözin açdı buldı özin nâz ile

Yigit oldı bislendi i'zâz ile

Dahı görmemişdür cihân işini

Ne yadını anlar ne biliş̧ini

Yola girüben zahmet ol görmedi

Garîblıkda oturmadı turmadı

Siz ana icâzet virün kim vara

Garîblıkda gezüp üşene ara
Vezir, Ey cihan padişâhl, senin huzurunda (söyleyecek) bir sözüm var, der.

$B u$ şehzademize çocukluğundan beri büyükler ve küçükler tarafindan iyi davranıldı̆̆ını bilin!

Gözünü açtı̆̆l günden beri kendini naz içinde buldu; izzetle yetiştirilip yiğit oldu.

Dünya işlerini de görmemiştir; ne yabancryı bilir ne dostunu.

O, yola koyulup hiç zahmet çekmedi; gurbet yerde ikamet etmedi.

Siz ona izin verin ki oraya ulaşsin; gurbette sikllip üzülerek yorgun düşün. 
Acıga vü yol zahmetine toya

Bu yoh endîşeyi tamâmet koya

Gelicek bu kez otura gitmeye

Şu yoh nesneyi ârzî itmeye

Bu 'ışka kim uğradı ol nâzenîn

Meger Tangrı işin onara hemîn

Gidenün yolın kimsene bă̆lamaz

Meseldür ki kendü düşen ağlamaz

Ko gitsün elinden gelürin ide

Ola kim bu sevdâ başından gide
Sikıntrya ve yol zahmetine doysun, bu olmayacak endişeyi tamamen biraksin.

$\mathrm{Bu}$ defa gelince otursun gitmesin; bu olmayacak şeyi arzu etmesin.

O narin yapılı, bu aşka uğradi; Allah onun bu işini hemen rast getirsin. (722-730)"

Giden kişinin yoluna kimse engel olamaz; atasözüdür ki, kendi düşen ă̆lamaz.

Bırak gitsin, gücünün yettiğini yapsın; belki bu sevda başından gider. (736737)”

Süheyl'in babası Bahr, Nakkaş'1 yanına çağırır. Nakkaş çok akıllı biri olduğu için ona güvenip oğlunu kendisine emanet ettiğini ve oğlunu çabuk getirmesi durumunda ona kendi tahtını vereceğini söyler. Nakkaş, dileklerinin gerçekleşmesi durumunda Süheyl'i çabucak getireceğine söz verir. Bunun üzerine Süheyl, Nakkaş’la birlikte yol hazırlığı yapar ve Çin’e doğru yola koyulur. Bu yolculuk Süheyl’in eğitim aldığı ve karakterinin geliştiği bir sürecin başlangıç noktası olur. Yolculuk esnasında Nakkaş, bir bakıma Süheyl'in akıl hocalığını yapmaktadır. Süheyl, karşılaştığ1 hemen her problemde danıştığ1 kişi Nakkaş olur. Süheyl de büyük oranda Nakkaş’ın tavsiyelerine uymaktadır.

Bildungsroman bağlamında kahramanın aydınlanma sürecini olumlu yönde etkileyen en büyük etkenlerden biri yolculuk sırasında yanında danıştığı biri veya birilerinin olmasıdır. Bu açıdan bakıldığında Süheyl'in yolculuk esnasında onun yanında olan, ona yol gösteren, karşılaştığı sorunları aşmasında onu bilgilendiren Nakkaş'ın bulunması bildungsromanın karakteristik bir özelliği olarak düşünülebilir:

“Gerek lutf idüp sen olasın bile

Ne kim sen dir isen alasin bile
Iyilik edip sen onunla birlikte ol! Her ne istersen yanına al! 
Uş oğluma yoldaş seni kıluram

Ki uslusin u key kişi bilürem

Eger tizcek oğlumı getüresin

\section{Geçüp tahtum üstinde oturasin}

Bu oğluma seni yoldaş olarak tayin ediyorum; çünkü sen aklllısin ve olgun biri olduğunu biliyorum.

Hemen oğlumu geri getirirsen benim tahtıma geçip oturursun. (779-781)”

Mesnevinin devamında Süheyl ile Nakkaş uzun bir yolculuktan sonra Çin'in yakınına varırlar. Süheyl'in durumuna çok üzülen Nakkaş, amacına ulaşması için Süheyl'e cömert olması gerektiğini, vardıkları şehirlerin hükümdarını, askerlerini, zengin ve fakir herkesi yemeğe davet edip onlara çeşitli hediyeler vermesi gerektiğini ve böylece iyi ününün her yerde yayılıp işinin kolaylaşacağını söyler. Süheyl, Nakkaş'ın söylediklerini yerine getirir ve böylece Süheyl amacına bir adım daha yaklaşır. Süheyl ile Nakkaş, karşılarına çıkan şehir halkına ve hükümdarına çeşitli ikramlarda bulunarak yollarına devam eder ve sonunda Çin'e varırlar. Süheyl, Nakkaş'ın tavsiyesi üzerine şehre yakın bir yerde konaklar. Nakkaş, Süheyl'e Çin hükümdarını korkutabileceklerini söylemesi üzerine Süheyl, bu söze karşı çıkar. Çin hükümdarının kendilerini düşman olarak düşünebileceğini ve gelip kendileriyle savaşabileceğini dile getirir. Bunun üzerine Nakkaş, Süheyl'e gerçekleştirmek istediği planını açıklar. Süheyl, Nakkaş'ın söylediklerini beğenir ve onu takdir eder. Nakkaş'ın söylediklerini uygulayan Süheyl, Çin hükümdarını ağırlar ve onun güvenini, dostluğunu kazanır. Böylece Süheyl, Nevbahâr'a ulaşma noktasında büyük bir aşama kaydeder. Süheyl'in yol arkadaşı olup akıl hocalığını yapan Nakkaş ise ilerde Yemen ülkesinin hükümdarı olacak Süheyl'e ilm-i siyaseti de öğretmeye başlamış olur.

Nakkaş'ın önerisi üzerine Süheyl, Çin hükümdarını tekrar yemeğe davet eder. Nakkaş, Süheyl'e Çin hükümdarının yanında nasıl davranması gerektiğini ayrıntılı bir şekilde anlatır. Ona, sarhoş olup sırrını açıklamaması gerektiğini söyleyerek onu uyarır. Hükümdar, Süheyl'in şarap içmemesini hoş karşılamayınca Süheyl, çaresiz kalır ve şarap içip sarhoş olur. Bir süre sonra Süheyl, kopuz çalıp şiir söyler. Nakkaş, hemen Süheyl'in yanına gelir ve sarhoşluğun etkisiyle sırrını açıklamaması için onu uyararak sabretmesi gerektiğini ifade eder. Ancak Süheyl, daha fazla dayanamaz kendinden geçerek şiirler söyler ve hemen yere yığılır. Nakkaş, farkında olmadan Süheyl'in işlemiş olduğu bu kabahati telafi etmeye çalışır ve hükümdara Süheyl'in henüz genç olduğunu babası tarafından kendisine emanet edildiğini dile getirir. Nakkaş ile hükümdar konuştuğu sırada Süheyl kendine gelir ve bir bahaneyle hükümdardan af diler. 
Görüldüğü üzere Nakkaş, Süheyl'in Çin hükümdarı ve halkı tarafından kabul görmesi, onlar tarafından saygınlık kazanması adına düzenlediği bu ziyafetlerde büyük oranda başarılı olur. Süheyl'in sadece akıl hocası değil aynı zamanda onun yanlışını düzelten, karakter olarak olgunlaşmasına yardımcı olan Nakkaş, onun amacına ulaşması için engelleri aşması adına elinden geleni yapan bir yol arkadaşıdır. Süheyl de yaptığı hatanın hemen farkına varan ve onu telafi etmeye çalışan bir kişiliğe sahiptir. Süheyl'in bu tutumu mesnevinin hemen her aşamasında görülür. Onun aklen ve rûhen gelişmeye açı eğitim yoluyla karşılaştığ 1 engelleri aşmaya çalışan ve sonunda aydınlanarak toplum tarafından kabul görmesine vesile olan bu tutumudur.

Olayların devamında Nakkaş, Nevbahâr'ın sarayına yakın bir saray inşa ettirir. Saray'ın bahçe kısmında güzel bir havuz yaptırır. Saraya gelen Süheyl'e, çeşitli tavsiyelerde bulunur ve Nevbahâr'ın suya düşen gölgesini gördüğü sırada ona hemen bakmaması gerektiğini öğütler. Süheyl ise sarayın bahçesinde kopuzu eline alır ve Nevbahâr'ın özlemini dile getiren şiirler söylemeye başlar. Ancak Nevbahâr'1 göremez. Süheyl, bu duruma çok üzülür. Nakkaş, Nevbahâr'ın dikkatini çekmesi adına ona ağır başlı olup sabretmesini, zengin fakir herkesi kendi sarayına davet edip onlara çeşitli ikramlarda bulunmasını, cömertliğini duyan herkesin saraya geleceğini ve böylece dileğinin çok yakında gerçekleşeceğini söyler. Süheyl, Nakkaş'ın dediklerini uygular ve daha sonra eline kopuzu alıp tekrar şiirler söylemeye başlar. Böylece, Nevbahâr'ın dikkatini çekmeyi başaran Süheyl, Nevbahâr'ın suya düşen gölgesini görünce dili tutulup kendinden geçer ve havuzun içine düşer. Süheyl'in havuza düştüğünü gören Nakkaş ve hizmetkârlar onu havuzdan çıkarır. Süheyl, Nakkaş'ın öğ̈̈dünü dinlememekle çok kötü bir iş yaptı̆̆ını söyler ve pişmanlığını dile getirerek ağlamaya başlar. Nakkaş ise sabretmesi yönünde telkinlerde bulunur.

$\mathrm{Bu}$ duruma benzer pişmanlıklar mesnevide birkaç defa daha tekrar eder. Süheyl, her defasında yaptığı hatadan ötürü pişmanlığını dile getirir ve Nakkaş'a söz verir. Ancak Süheyl, Nevbahâr'1 gördüğü sırada verdiği sözleri unutup kendinden geçer ve yine aynı hataya düşer. Mesnevide geçen buna benzer olaylardan bir bölümü şöyledir:

"Tama ă̆dı vü bâğa kıldı nazar

Girü gölgesi suya düşdi meger

Süheyl anı gördi vü yumdı gözin

Tağıtmadı 'aklın u dirdi özin
Dama çıktı ve bahçeye baktı; gölgesi meğer tekrar suya düştü.

Süheyl onu görünce gözünü yumdu, akılsızca işler yapmadı ve kendini toparladl. 
Çü gördi ki ol kendüzin sakınur

Ne oynar ne çevresine bakınur

Bölük saçlann çözdi uzatdı hoş

Sanasin kemend idi uz atdı hoş

Tola geldi bâğ içi müşk ü 'abîr

$B u$ 'ışıı neler ögredür gör ya bir

Melik-zâde ol saçlarl göredi

Girihlerine gönlini viredi

Nakâş̧un ögüdin kodı bir yana

Kişi esriyicek ne ögüt ana

Başın kaldurup ansuzın bahtı ol

Yire nâmûsın küllî bırahtı ol

Sevindi şu bahduğına Nev-bahâr

Didi kim bu yâr olmağa key yarar

Bayık bildi kim kıldı 'ışka şikâr

Olur kanda var ise "ş̧ âş̧ikâr

Ana karşu hoş güldi bir gül bigi

Anı mübtelâ kıldı bülbül bigi

Çü ma 'şûka kan dökmege diş biler

Isşi evvel oldur ki yüze güler

Dirişdürdi saçlarını tîzcegin

Revân oldı aldı Süheyl'ün ögin
Nevbahâr, Süheyl'in hareket etmediğini, etrafina bakmayıp çekingen davrandığını gördü.

Bölük bölük olan saçlarını çözüp o kadar uygun bir şekilde uzattı ki saçlarının kement olduğunu sanırdın.

Bahçenin içi misk ve güzel kokularla doldu; bu aşkın neler ögrettiğini bir gör!

Şehzade o saçlarl görünce o saçların düğümlerine gönlünü kaptırdl.

Nakkaş'ın öğüdünü bir kenara bıraktı; kişi sarhoş olunca akla hangi ögüt gelir?

Aniden başını kaldırıp baktı; namusunu ayaklar altına ald .

Nevbahâr onun kendisine bakmasina sevindi ve bu, sevgili olmak için çok uygundur, dedi.

Aşka, av olduğunu iyice anladl; aşk neredeyse ortaya çıkar.

Ona karş̧ hoş bir gül gibi gülüp onu bülbül gibi tutkun hale getirdi.

Sevgili, maşukun kanını dökmeye arzu duyduğu için onun işi ilk önce yüze gülümsemektir.

Saçlarını çabucak topladı; Süheyl'in aklını başından alarak hemen yürüdü. 
Bile gitdi kodı yirinde anı

Nite kim gide cân bırăga teni

Düşüp yatur idi ne 'akl u ne fehm

Ne hûşü ne fikr ü ne tedbîr ne vehm
Canı, kendi bedenini bırakmış gibi

onu orada birakip yanından gitti.

Akılsız, anlayışsız, sersem, düşüncesiz, tedbirsiz ve kuruntusuz bir şekilde bayılmış yatıyordu. (15551569)”

Bu durum, Süheyl'in akıl ile kalp arasında sıkıșıp kaldığı bir süreç olarak da algılanabilir. Nihayetinde Süheyl, Nakkaş'ın yani aklın tembihlediği gibi davranır ve Nevbahâr'ı kendisine âş̧ı eder. Bildungsroman bağlamında tüm bu süreçlerin Nakkaş tarafından tavsiye niteliğinde verilen öğütlerin ve yaşam tecrübelerinin eğitim yoluyla elde edilen bir kazanım olarak görmek mümkündür.

Birbirlerine âşık olan Süheyl ile Nevbahâr, daha çok görüşebilmek için yeraltında bir tünel yaparlar. $\mathrm{Bu}$ tünelin ortasında ise buluşup muhabbet edecekleri bir oda inşa ederler. Bu odada gizlice görüşüp hoşça vakit geçirirler. Bir gün Süheyl'in aklına yaşlı anne ve babası gelir ve onları yâd ederek Nevbahâr'ın yanında âh eder. Nevbahâr'ın sorması üzerine Süheyl, anne ve babasının durumlarını merak ettiğini onların yanına beraber gidebileceklerini söyler. Süheyl, Nevbahâr'ın tavsiyesi üzerine oradan ayrılmak için Nakkaş’1 izin istemek üzere Çin hükümdarının yanına gönderir. Ancak hükümdar, izin vermez ve ertesi gün onları yemeğe davet eder. Süheyl davete icabet edip gece yarısı olunca Nevbahâr'ın yanına gelir ve ona kaçmak için ne yapabileceklerini sorar. Nevbahâr ise kaçmak için askeri alıp hazırlık yapmak üzere Nakkaş'a haber vermesini söyler. Süheyl, Nakkaş'ın yanına gelir ve durumu anlatır. Nakkaş, bu duruma itiraz etse de yapacak bir şey yok diye askeri hazırlar ve şehrin dışında Süheyl ile Nevbahâr'ın gelmesini bekler. Nevbahâr ise kılık değiştirip meclistekilere şarap sunar. K1lık değiștiren Nevbahâr'dan șüphelenen baba onu konuşturmaya çalışır. Durumun kötüye gittiğini gören Süheyl ise yaptıklarından pişman bir şekilde Allah'a dua eder. Nevbahâr, saraydan kaçması durumunda Süheyl'e nerede bekleyeceğini ve ne yapacağını anlatır. Ayrıca kendisini beklerken uyanık olması gerektiğini de söyler. Süheyl, Nevbahâr'ın söylediklerini unutur ve bekleme yerinde uykuya dalar. Süheyl'in uyuduğunu gören Saluk, Süheyl'in hazırladığı atları alır ve orada bir süre oyalanır. Saraydan kaçıp buluşma yerine gelen Nevbahâr, Saluk'u Süheyl sanarak onun peşinde yürür ve Süheyl'in yanından uzaklaşır. Süheyl uykudan uyandığı sırada atların yanında ve Nevbahâr'ın şehirde olmadığını görür. Nevbahâr'ın sözünü dinlemeyip uykuya daldığ 1 için kendine kızarak feryat edip ağlamaya başlar. Tabi bu durumdan da pişmanlığını defalarca dile getirir. Süheyl'in saraydan kaçıp gelmesini bekleyen Nakkaş ise Süheyl'in gecikmesi üzerine tedirgin olur. 
Nakkaş, onun gibi hata yapabilecek durumda olan genç ve tecrübesiz birini yalnız bıraktığı için kendini suçlamaktadır.

Görüldüğü üzere Süheyl, hem yoldaşı hem de akıl hocası olan Nakkaş yerine sevdiği kız olan Nevbahâr'ın sözlerini dinlemeye başlar. Nakkaş yine de hatalarını telafi etmek için elinden geleni yapmaya çalışır. Ancak uzun süren çabanın ardından elde edilen mesut günlerin yerini yavaş yavaş ayrilık ve keder alır. Tabi bu durum, Süheyl için ayrı bir tecrübe ve eğitimin kapısını aralar. Çünkü hikâyenin devamında Süheyl, Nevbahâr'ı aramak için bir süre tek başına seyahat eder. Seyahat esnasında karşılaştığı kişi ve olaylar onu ahlak, düşünce ve duygu açısından tekâmüle eriştirir. Nitekim bu eğitim olgusu bildungsromanın temel özellikleri arasında yer alır.

Nevbahâr'1 kaybeden Süheyl'in durumu gün geçtikçe kötüleşir. Çaresiz bir şekilde Nevbahâr'ı aramak için yollara düşen Süheyl, Câlûs adında bir yiğitle karşılaşır. Câlûs, onun aç, susuz ve yorgun olduğunu görünce onu kalesinde ağırlar. Süheyl'in kederli haline daha fazla dayanamaz ve onun kaygısını giderecek öğütler vermeye başlar. Câlûs, Süheyl'in kendine olan özgüvenini tekrar kazanması için çabalar. Süheyl, Câlûs'un ögütlerini dinledikten sonra ona başından geçenleri anlatır. Câlûs ise Nevbahâr'ı bulmak adına Süheyl'e yardım edeceğine söz verir. Bunun üzerine Câlûs Çin'e casuslarını yollar. Casusların Çin'den getirdiği haberleri işiten Süheyl, canından usanmış bir şekilde hüngür hüngür ağlamaya başlar. Eskiden herkesi kıskandıracak nitelikte şan şöhret sahibi bir şâh olan Süheyl, şimdi çok zavallı ve esirgenecek bir dilenciye döner ve yaptıklarından pişmanlık duyar. Süheyl bu durumda iken onun dert ortağı yine Câlûs olur. Câlûs, Süheyl'i bu kötü durumdan uzaklaştırmak için ona tekrar öğütler vererek teselli eder. Süheyl, biraz olsun kendine gelmeye başlar ve Câlûs'a bu davranışı için teşekkür eder. Bir gün Câlûs ile Süheyl mecliste otururken iki yüz atlının yoldan geçtiği haberini alırlar. İyi bir savaşçı olan Süheyl savaşa hazırlanır ve Câlûs'la birlikte iki yüz atının yolunu kesmeye giderler. Savaş sırasında Süheyl'in hemen her savaş aletini ustaca kullanması Câlûs'un dikkatini çeker. Ancak Süheyl'in atının sürçüp düşmesi sonucu Süheyl, Çinli atlılar tarafindan yakalanır ve Câlûs ise kaçmak zorunda kalır. Câlûs onun yakalanmasına çok üzülür ve Süheyl gibi bilgili, kibar, kahraman, sohbet arkadaş1 birinin zor bulunabileceğini söyler.

Seyahati sırasında Süheyl'in karşısına çıkan Câlûs, Nakkaş'ın yerini alır. Câlûs, onu teselli etmeye çalışır ve ona öğütler verir. Bir süre Süheyl'in akıl hocası konumunda ona yol gösterici olur. Süheyl'in Nevbahâr'a kavuşması adına elinden geleni yapar. Ancak Süheyl, yaşadığı bir talihsizlik nedeniyle Nevbahâr'a kavuşamadan Câlûs'un yanından ayrılır. 
Bu sırada Nevbahâr da Süheyl'i arayıp bulmak adına uzun bir seyahate çıkar. Seyahat sırasında pek çok sıkıntı çeken Nevbahâr sonunda Tûfân şehrine gelir ve bu şehrin hükümdarı olur.

Mesnevinin devamında Süheyl ile Nakkaş Hâverân şâhının ülkesinde karş1laşır. Birlikte Yûn şehrine gelirler. Yûn şehrinin hükümdarı, Süheyl ile Nakkaş'1 zindana atar. Çok zor durumda kalan Süheyl, zindan bekçisine yalvarır ve zindan bekçisinin sayesinde Süheyl ile Nakkaş zindandan kurtulur. Süheyl ile Nakkaş bir süre yol aldıktan sonra Tûfân şehrine varırlar. Şehre vardıklarında su içmek için suyun bulunduğu havuza giderler. Havuzdan su almak için giden köle, orada gördüğü resmi Süheyl'e anlatır. Süheyl, o resmi görür ve kendinden geçerek bayılır. Bayılan Süheyl'i ve Nakkaş'1 Tûfân şehrinin hâkimi olan Nevbahâr' 'n huzuruna getirirler. Yüzü peçeli bir şekilde olan Nevbahâr, onlara çeşitli ikramlarda bulunur ama kendini onlara tanıtmaz. Nevbahâr, birkaç gün geçtikten sonra meydanda bir taht kurar ve halkı buraya davet eder. Tahta oturan Nevbahâr'ın sağında Süheyl, diğer tarafında ise Kaytâs vardır. Cühûd ile Saluk ise bir köşede beklemektedir. Nevbahâr önce Saluk'a söz hakkı verir ve başından geçenleri anlattırır. Cühûd ve Kaytâs da başından geçenleri anlattıktan sonra sıra Süheyl'e gelir. Süheyl, kubbedeki resme bakıp Nevbahâr'a âşık olduğunu, onu bulmak için her şeyi terk edip Çin'e gittiğini, Nevbahâr'ı nasıl kaybettiğini ve yolda çektiği sıkıntıları anlatınca orada bulunan halk ağlamaya başlar. Nevbahâr, daha fazla dayanamaz ve halkın önünde Çin hükümdarının kızı Nevbahâr olduğunu açıklar. Nevbahâr halka, Süheyl'in hükümdar olması gerektiğini ve kendisinin de Süheyl' in eşi olacağını söyler.

Süheyl, Nakkaş'1 kendine vezir tayin ettikten sonra Cühûd ve Saluk'a gerekli cezayı verir. Kaytâs'a ise ikramlarda bulunarak onu şehirden gönderir. Süheyl ile Nevbahâr evlendikten sonra yaşadıkları sıkıntıların sonlanması üzerine Allah'a şükrederler. Süheyl daha sonra Çin hükümdarına kendi durumlarını açıklayan bir mektup yazar ve ondan af diler. Mektubu alan hükümdar çok sevinir ve onlara oğluyla birlikte hediyeler göndererek onları affettiğini dile getirir. Süheyl, Hâverân şâhına ve Câlûs'a da mektup yazdıktan sonra babasına da kendi durumunu anlatan bir mektup yollar. Bu mektupta babasının sözünü dinlemediği için pişman olduğunu, ögüdünü dinlemediği için pek çok belayla karşılaştığını, hazinenin tükendiğini ve Çin hükümdarıyla savaşan ordunun dağıldığını dile getirir. Mektubun sonunda ülkeyi terk ederek cahillik ettiğini ifade ederek babasından af diler. Mektubu okuyan Süheyl'in babası bu duruma sevinir ve onu yanına çağırır. Süheyl, tahtı kendi oğlu Hümâm'a bırakarak Yemen'e gider. Oğlunu gören Yemen hükümdarı Bahr, çok sevinir ve sıkıntıları aşıp muradına eren Süheyl’i tebrik ederek ona iltifat eder.

Bir süre sonra Süheyl'in babası hastalanır. Süheyl'in babası, ölüm döşeğinde iken Süheyl'e ve orada bulunan beylere pek çok nasihatlerde bulunur. Tahtını 
Süheyl'e verdiğini söyledikten sonra oğluyla vedalaşıp vasiyetini dile getirir ve vefat eder. Babasının ardından feryat edip ağlayan Süheyl, ona doyamamanın acısını yaşar. Babasının vefatının ardından Yemen hükümdarı olan Süheyl, babasının öğütlerini dinleyip uygular. Böylece Süheyl, dünyada eşi benzeri olmayan iyi ve yüce bir padişâh olur.

Mesnevinin sonunda görüldüğü üzere Süheyl, uzun soluklu bir maceranın ardından pişmanlığını dile getiren mektuplar yazar. Af dilemek için yazdığı bu mektupları onun hem zihinsel hem karakter gelişimi bağlamında nihâyî bir nokta olarak görülebilir. Bildungsroman açısından değerlendirildiğinde başta Süheyl'in bazı değer çatışmalarının içine sürüklendiği fakat olaylar geliştikçe ve öğrendikçe mensubu olduğu grubun değerlerine uyum gösterdiği ve toplum tarafından kabul gördüğüne şahit olunur. Bu durum, aynı şekilde tinsel dönüşüm içinde olan Süheyl'in aydınlanmasına da bir delil olarak gösterilebilir.

\section{Sonuç}

Süheyl ü Nevbahâr mesnevisi gibi klasik Türk edebiyatında yer alan iki başkahramana sahip pek çok mesnevide genellikle bir yolculuk vardır. Bu yolculukta kahramanların, aldığı eğitim sayesinde ahlak, düşünce ve duygu gibi kişisel gelişimleri bildungsroman açısından değerlendirilebilir. Böylece, bu çalışmada da görüldügü üzere mesnevide yer alan kahramanların karşılaştı̆̆ 1 zorluklar neticesinde edindiği tecrübeler, gelişim süreci okur tarafindan dikkatli bir şekilde takip edilebilir.

$\mathrm{Bu}$ bağlamda bildungsromanın temel özelliklerinin başında, kahramanın aldığ1 eğitim yoluyla karakter olarak gelişmesi ve hayatta karşısına çıkan engelleri aşması gelir. Süheyl ü Nevbahâr mesnevisinde de bu durum görülür. Zira mesnevide Süheyl, Nakkaş'ın ve seyahat esnasında karşılaştığı diğer şahsiyetlerin yol göstericiliği ile olgunlaşmış, aldığ 1 eğitim ile birçok konu hakkında aydınlanmıştır. Edindiği tecrübe ve eğitim sayesinde Süheyl, bir nevi Yemen ülkesini yönetmek üzere hazırlığını tamamlayarak dönüş yolunu tercih etmiştir. Ancak bu dönüş yolunda işlediği hataların farkına varıp pişmalıklarını dile getirmiştir. Süheyl, seyahati esnasında yaşadığ her tecrübede ve aldığ 1 eğitim neticesinde karşılaşacağı bir sonraki olay için daha donanımlı hâle gelmiş, babasının özlem duyduğu yönetici konumuna erişmiştir. Halk tarafından da kabul gören Süheyl, geri kalan yaşamını babasının isteği doğrultusunda geçirmiştir. Görüldüğü üzere Süheyl, çocukluğundan itibaren yaşadığı değişim ve olgunlaşmanın nihayetinde kendi kararlarını verebilecek bir düzeye erişmiş ve toplum tarafından kabul görmüştür. Bir bakıma Süheyl'in gelişimi ve sonrasında kemâle ermesi, çalışmanın ilk bölümünde de bahsedildiği üzere bildungsromanın maddeler hâlinde sıralanan 8 temel özelliği ile örtüşmektedir. 
Süheyl ü Nevbahâr gibi bireyin eğitimi/gelişimi açısından her çağın insanına hitap eden pek çok klasik eserimiz mevcuttur. Bu eserlerin, temel kıstaslara riayet edilerek yeni bağlamlar eşliğinde değerlendirilmesinin eser ve okur arasındaki irtibatı daha güçlü kılacağı ve böylece anlatıda gözden kaçan bir kısım tecrübelerin, nasihatlerin veya mesajların okur tarafından net bir şekilde görülebileceğini söylemek mümkündür.

\section{KAYNAKÇA}

Abrams, M. H. (1999). A glossary of literary terms. Heinle \& Heinle.

Aytaç, G. (1990). Edebiyat yazıları I. Gündoğan Yayınları.

Bayram, Y. (2007). Bildungsroman olarak 'Hüsn ü Aşk', İlmi Araşstrmalar Dergisi, 23, 7-28.

Bingöl, U. (2019). Postmodernizmden modernizme eleştiri terimleri sözlüğü I. Akademik Kitaplar Yayınevi.

Boes, T. (2006) Modernist studies and the bildungsroman: a historical survey of critical trends. Literature Compass, 3(2). England: Blackwell Synergy.

Ciğa, Ö. (2013). Süheyl ü Nev-bahâr metin-aktarma, art zamanl anlam değişmeleri, dizin, [Yayınlanmamış yüksek lisans tezi]. Dicle Üniversitesi.

Dilçin, C. (1991). Süheyl ü Nev-bahâr inceleme-metin-sözlük. Atatürk Kültür Merkezi Yayını.

Dilthey, W. (1985). Poetry and experience. (trans. Rudolf A. Makkreel and Frithjof Rodi). Princeton University Press.

Kütük, R. (2004). Bireyin eğitimini konu edinen bir eser olarak Lârendeli Hamdî’nin Leylâ ile Mecnûn mesnevîsi. A. Ü. Türkiyat Araştırmaları Enstitüsü Dergisi, 24, 67-83.

Minden, M. (1997). The german bildungsroman. Cambridge University Press.

Parla, J. (2012). Don Kişot'tan bugüne roman. İletişim Yayınları.

Thamarana, S. (2015). Origin and development of bildungsroman novels in English literature. IJELIH III, VI, 21-26.

Tökel, D. A. (2009). Bu alamet ile bulur beni soran: Fuzuli kitabı. İçinde M. Çakır ve H. Koncu (Eds.), Bir bildungsroman olarak Leyla vü Mecnûn mesnevisi (ss. 179-193). Kesit Yayınları. 